\title{
«CAMBIAR EL MUNDO»: ¿JUSTICIA O UTOPÍA?
}

\author{
Jorge E. Douglas Price 1
}

\begin{abstract}
RESUMEN: El ensayo juega irónica y borgeanamente, con la idea de que la expresión «Cambiar el mundo»: ¿justicia o utopía?, que no se encuentra en El Quijote, pudiera sin embargo haber sido excluida de él, o bien inventada por un autor anónimo, recurso habitual en la edad media. Señala que estamos en presencia de obras que, en algún modo, marcan el comienzo del concepto de "autor" y, paradójicamente, lo cuestionan, como lo hace Cervantes de modo deliberado, o como queda retratado en las dificultades para establecer la verosimilitud de la autoría de las obras del bardo inglés. Y esto lo hace para trabajar, no sólo por la coincidencia de las fechas de sus muertes (que otorga espacio para otro juego borgeano), sino por su contribución a la conformación del universo cultural occidental, que llevara a Bloom a la exageración de atribuir a Shakespeare "la invención de lo humano", sino para formular la oposición de dos éticas entre dos personajes emblemáticos como el propio Quijote y Lady Macbeth: la ética, que luego llamaríamos "del deber", desde la que se construye el concepto de utopía, presente en la obra de Erasmo de Rotterdam (de enorme influencia en la España de Cervantes) y en la de Tomás Moro; y la ética, que luego llamaremos pragmática, la ética de Lady Macbeth, que prescribe a su esposo los consejos de Nicolás Maquiavelo. En suma, sostiene que Cervantes y Shakespeare inauguran la modernidad, que las ideas que encontramos en sus obras, que estaban presentes en la producción de sentido de su tiempo, a su vez, lo alteraron (dado el efecto performativo de la literatura); y que, sus entrañables personajes, unidos por el hilo invisible de la "locura", permiten ver las dos caras de lo humano, como en los silenos de Alcibíades.
\end{abstract}

PalabRas Clave: modernidad; ética; Erasmo; Maquiavelo; utopía; performatividad.

1 Profesor Titular Teoría General del Derecho I y II, Facultad de Derecho y Ciencias Sociales, Director del Centro de Estudios Institucionales Patagónico (CEIP), Universidad Nacional del Comahue, Argentina. E-mail: jorgedouglas952@gmail.com 


\section{¿QUIÉN Y POR QUÉ ESCRIBE ESTE ENSAYO? O "UNA INTRODUCCIÓN ANÓMALA"}

Como Uds. saben, hay un autor subrepticio que ignora pertinazmente los derechos de sus colegas. Un autor que, para huir de la justicia (digámoslo bien: de la administración de justicia), se hace llamar en ocasiones Anónimo, en otras Apócrifo, en las más de las veces Vox Populi, en unas pocas y más reservadas, Vox Dei, pero, en las más sublimes, simplemente el "Heterónimo", recurso más conocido en Portugal, que en otras partes.

Es, como ya habrán advertido, un autor premoderno, porque uno de los "inventos" más complejos de la modernidad es el de autor y su lógico correlato, el de plagio, conceptos que aquél parece ignorar por completo. Yo también.

Bien, de un refrán de este autor, que no de Cervantes, deriva el título de esta conferencia "so para contrariar", y los invito a acompañarme en un juego que terminará enfrentando ficcionalmente a los personajes de Cervantes y de Shakespeare intentando contestar el dilema del título.

Ello en parte porque al mismo Cervantes le placería que se inventasen historias del Quijote que nunca sucedieron en la realidad (como la que fraguara el impertinente, falaz y oportunista Avellaneda, que lo forzó a apurar la segunda parte de su historia); pero, en parte también, porque quien quiera que haya sido el inventor de este falso dilema (desde que como se sabe todo acto de justicia funge hoy como utopía), pasaría por ser un heterónimo (tal vez pobre de letras, pero heterónimo al fin).

Claro que tampoco sabríamos quién es heterónimo de quién, porque sabemos que no es Cervantes el autor del Quijote, él mismo aclara que es padrastro y no padre del caballero de la Triste Figura (De Cervantes Saavedra, 2015, p. 7) y más tarde nos cuenta que encontró el manuscrito de la historia, luego de la batalla con el vizcaíno, al comprar unos cartapacios a un muchacho de Toledo (De Cervantes Saavedra, 2015, p. 86), en el primero de los cuales se representaba con una pintura, muy vívidamente, la referida batalla.

Trataré, sin embargo, de probar en este ensayo (que no cumple acabadamente con las reglas del ensayo) por qué el autor original del Quijote podría haber escrito esa línea, o, mejor aún, que esa línea pudo estar en el original que Cervantes dio a la imprenta, pero que fue olvidada 
“deliberadamente" por su editor temeroso del poder real, de ese ánimo de conservación que todos los poderes constituidos observan, pero que, no obstante, ha llegado hasta nosotros por tradición oral.

Ese aforismo, que muchos de ustedes conocen, tanto como el de "ladran Sancho, señal que cabalgamos" (que también es apócrifa o más bien tomada prestada de Goethe, que, a su vez, pudo haberla tomado de un refrán turco이, demuestra - en primer lugar - que muchos de nuestros más preciados escritores terminan siendo usufructuados por el saber popular, tanto como usufructuarios del mismo (al que luego pasan por inventar) y terminan por ser, en cierto sentido, plagiarios.

La frase a la que me refiero, en su versión más divulgada, dice: "Cambiar el mundo, amigo Sancho, no es locura ni utopía, mas síjusticia”.

La construcción literaria no está muy lograda, si al estilo nos referimos, y es poco cervantina (o si quieren Uds., poco imputable al autor del Quijote), pero deberíamos considerar la posibilidad de que el traductor desconocido de la historia de Alonso Quijano, aquél morisco que pasara la obra del árabe al español, según relata Cervantes, haya tenido como lengua materna el árabe, lo que explicaría algunos de los fallos de la obra (y también de la traducción de la frase, aunque de todos modos debemos recordar que traducir es Decir casi lo mismo como otro hallador de manuscritos lo ha señalado3); a ello se habría sumado una omisión deliberada por parte de don Francisco de Robles, librero y negociante, especializado en publicaciones oficiales y obras jurídicas quien, en su carácter de Librero del Rey, no podía dejar pasar una frase tan abiertamente subversiva.

2 La mayoría de los expertos señalan que la primera constancia escrita de una expresión similar, y que podría haber dado origen a esta, fue obra del poeta alemán Johann Wolfgang von Goethe, quien en 1808 publicó el poema titulado 'Ladran' (Kläffer), el cual decía: En busca de fortuna y de placeres

Más siempre atrás nos ladran,

Ladran con fuerza...

Quisieran los perros del potrero

Por siempre acompañarnos

Pero sus estridentes ladridos

Sólo son señal de que cabalgamos

Todo parece ser que fue de este poema de dónde sacó (casi un siglo después) Rubén Darío la inspiración para acuñar una expresión que solía decir cuando era criticado debido al mestizaje de su origen. Dicha expresión ya traía incorporado el nombre de Sancho, pero lo que no se sabe es porqué el poeta nicaragüense se la añadió: 'Si los perros ladran, Sancho, es señal que cabalgamos', cabe destacar que hubo incluso quien quiso atribuírsela a Miguel de Unamuno.

3 Así titula Umberto Eco (2008) a su ensayo sobre la traducción, y es conocido que apela a este recurso, el del hallazgo de un manuscrito, en su célebre novela El nombre de la rosa. 
Tal vez, la omisión tuvo un origen mucho menos ominoso, y simplemente se debió a un error del regente del taller, Juan de la Cuesta, a cargo de la confección material, pero, y esto es lo importante, lo cierto es que la frase pudo haber sido acuñada por entonces, desde que Cervantes y el autor real del Quijote, ambos lectores impenitentes, como el mismo Cide Hamete Benengeli y hasta el mismo traductor morisco, del que poco sabemos, pudieron haber leído el célebre y no menos improbable relato de Tomas Moro, publicado en 1516, de donde seguramente surgieran las ideas de la famosa Isla de Barataria, cuyo gobierno Sancho comienza con ideas tan subversivas como las de esa frase, pero sobre ello volveré más adelante.

Similares dificultades encontramos con respecto a la autoría de las obras de Shakespeare, que comienzan por las diferencias de la publicación in-quartos, ocurrida en vida del bardo, y la publicación in-folio de 1623. Afirman los peritos que de ningún autor existen textos que hayan llegado más corruptos hasta nosotros, fuera de los poemas Venus y Adonis y La violación de Lucrecia, que el propio Shakespeare - de haber existido realmente - debió revisar por sí mismo. A su muerte sólo dieciséis de sus obras dramáticas se habían editado, todas ellas in-quarto, ninguna con su consentimiento, sino trabajo de editores piratas que se movían en el entorno de los autores teatrales y eran copias tomadas de oído, plagadas de errores. Siete años después de su muerte, sus amigos y actores, John Heminge y Henry Condell, remediaron en parte aquellos fraudes, dando su propia versión, en el in-folio de 1623 y en ella, el prólogo dedicado «A la gran variedad de lectores»; la muerte impidió que el mismo bardo corrigiese esta edición, pero como él era un feliz imitador de la Naturaleza, y "juntas marchaban su imaginación y su mano", apenas hicieron alguna corrección a sus papeles (Astrana Marín, 2003).

Para mayor desasosiego nuestro, la crítica inglesa se ha empeñado en sostener que Shakespeare no escribió las obras que bajo su nombre conocemos, sino que lo hicieron otros - presuntamente más preparados o más cultos que él - como el decimoséptimo conde de Oxford, Edward de Vere, o el mismísimo Francis Bacon, quien habría inventado su heterónimo en clave masónica, que prueba de ello sería el que los nombres de ambos reunidos suman treinta y tres letras (lo que comporta un símbolo de la masonería), otra prueba de su autoría se encontraría en los paralelismos 
que se pueden encontrar entre sus obras, o en las anotaciones en su libro de notas personal y en las coincidencias autobiográficas halladas en los textos que se imputan al bardo de Stratford upon Avon. Walt Whitman, por su parte, se inclinó por la autoría del conde de Oxford, al igual que Sigmund Freud.

Borges diría, con su habitual ironía, que la discusión carece de sentido, que en todo caso un inglés de esa época escribió las obras que aparecen bajo el nombre de Shakespeare y que la pasión trágica, prosperaba en ellas incluso contra las malas traducciones, las malas puestas en escena o los malos actores, tal como lo describe en el prólogo a su traducción de Hojas de Hierba.

Por mi parte quisiera sostener que estas dudas que sembraron los oxfordianos y el propio Cervantes no hace sino probar que la autoría es per se un concepto dudoso, que de hecho tiene su propia historia semántica y legal, un concepto que podríamos proponer abandonar.

Sabemos que ambos autores murieron en el mismo día de calendarios diferentes (invención que podría atribuirse con cierta comodidad a Borges) y que, para nuestro desasosiego, Anthony Burguess echó a correr la idea de un encuentro improbable en Valladolid (Burguess, 1987).

\section{¿DE DÓNDE SURGE NUESTRA MEMORIA DEL SENTIDO?}

La enferma Anna O., de la que habla Josef Breuer, el colega de los primeros pasos de Freud, tras sufrir la muerte de su padre, sufre una emoción violenta seguida de un profundo estupor, en el que prácticamente no reconoce a las personas, en ese cuadro solo habla en inglés, ya no en alemán, y mientras lee en francés e italiano da con presteza una traducción al inglés, tras ello comienza a escribir con la mano izquierda en letras de imprenta con un alfabeto que construye a partir de Shakespeare (Breuer, 1999).

Vamos a parafrasear a Shakespeare (o quien quiera que sea que escribiera Macbeth): ¿Quién podría no pensar que en la memoria de todo individuo se asienta la capacidad de escribir "esas" tragedias? ¿Por qué habría de serlo sólo en la de un noble culto? 
Sé que tal interpretación aterrorizaría a Freud, por su sonido "junguiano", pero en este punto ya comprenderán que este ensayo tienta de ser un "scherzo sul serio".

Digámoslo de una vez: la estructura de la sociedad, que está compuesta de comunicaciones, tiene - obviamente - base semántica, y, tal como podemos derivar de Luhmann, el patrimonio de las ideas que operan en el rapport de la sociedad consigo misma, con la propia sociedad que las usa, no puede variarse arbitrariamente no ya en el sentido - ni mucho menos - de que las ideas estén predeterminadas al modo platónico, sino porque siempre hay un set de ideas que configura el telón de fondo sobre el que se crea nuevo sentido (una cosa que los tribunales suelen olvidar).

En suma, parto de sostener que la ideas que encontramos en Macbeth; Don Quijote, Lady Macbeth; Sancho, Hamlet y Laertes (como lo podríamos hacer en Edipo Rey, Medea, Antígona, Las nubes), estaban ya presentes en la producción de sentido de su tiempo, pero, a su vez, lo alteraron:

[...] el punto de partida es que todas las vivencias y las acciones humanas se desarrollan conforme el sentido y son a sí mismas accesibles son en conformidad con el sentido [...] Cada sentido contiene así una suerte de garantía de ligazones con ulteriores vivencias y acciones y una garantía para la recurrencia, para el retorno a si mismo después de haber sido pasado por otros contenidos de sentido [...] El sentido así entendido tiene realidad solo en el cumplimiento actual $\mathrm{y}$ por esto siempre presente (Luhmann, 1983, p. 15, corregida grafía de apellido de Luhmann) 4 .

De allí que me proponga sostener que la idea de utopía que está presente, que "aparece" de modo tan visible en El Quijote, y más subrepticia o especularmente en Macbeth, Hamlet o Enrique V, es un sentido que comenzó a sedimentarse en el siglo XV y ha llegado hasta nuestros días. En suma que Moro y Erasmo son un paño de fondo.

En suma, sostener - literatura mediante - que Cervantes y su colega de Stratford-upon-Avon, cambiaron el mundo, reflejando el cambio del mundo, proyectándolo hasta donde el sentido de su tiempo permitía enlazar.

4 Traducción de la versión italiana por el autor de este ensayo. 


\title{
EL MÉTODO PARADOJAL DE LA LITERATURA MODERNA
}

Debo ahora advertir sobre los paradojales resultados de esas obras (de todas las obras potencialmente), o, si Uds. quieren, sobre el efecto performativo de la literatura, tanto por lo que dice como por lo que calla 5 , algo que el propio Cervantes no ignoraba puesto que su entrañable personaje perdió la cordura por el hábito de leer novelas de caballería, recurso que, si lo advierten, utiliza también en el Licenciado Vidriera; personaje que si bien no pierde la razón por leer, es leyendo por lo que alcanza fama, y por lo cual una dama non sancta le da la pócima que lo trastorna hasta hacerle creer que se ha transformado en un hombre de vidrio, aspecto del relato que bien puede considerarse una parodia del bíblico, la ironía es sutil: la manzana es reemplazada por un membrillo y la pérdida del Edén por la de la razón.

El tema de la locura, fue un tema que nuestros autores, sondearon con maestría, mostrando como la distinción entre ella y la cordura, está formulada por un observador que no sabe desde dónde observa, como ningún observador lo sabe, ni sabe, tampoco, con cual razón señala cuál es la razón que tiene la razón para considerarse racional. Lo advierte Foucault al señalar que la locura posee su propio discurso académico, reivindica una posición más cercana a la felicidad y a la verdad que la razón, más cercana a la razón que la misma razón y en el centro de esos juegos están los textos de los grandes humanistas, Flayder y Erasmo (En alusión a Moria Rediviva, del primero y el célebre Elogio de la locura - o la Estulticia - del roterodamo). Es posible, dice Foucault,

\begin{abstract}
que las naves de los locos que enardecieron tanto la imaginación del primer Renacimiento; primeros navíos, hayan sido navíos de peregrinación, navíos altamente simbólicos, que conducían locos en busca de razón [...] la barca simboliza toda una inquietud surgida repentinamente en el horizonte de la cultura europea a fines de la Edad Media. La locura y el loco llegan a ser personajes importantes, en su ambigüedad: amenaza y cosa ridícula, vertiginosa razón del mundo y ridiculez menuda de los hombres (Foucault, 1990, p. 23 e 28).
\end{abstract}

5 Según Judith Butler: "Una orden puede ser tan eficazmente ejercida mediante el silencio como mediante su formación verbal explícita. Infiero que incluso una conducta silenciosa podría valer como performativo lingüístico en la medida en que entendamos el silencio como una dimensión constitutiva del habla”. 
La denuncia de la locura, prosigue Foucault, llega a ser la forma general de la crítica, en el teatro las figuras de los locos ya no ocupan una posición marginal, ocupan el centro de la escena

\begin{abstract}
representando el papel complementario e inverso del que representa la locura en los cuentos y en las sátiras. Si la locura arrastra a los hombres a una ceguera que los pierde, el loco, al contrario, recuerda a cada uno su verdad; en la comedia, donde cada personaje engaña a los otros y se engaña a sí mismo, el loco representa la comedia de segundo grado, el engaño del engaño; dice, con su lenguaje de necio, sin aire de razón, las palabras razonables que dan un desenlace cómico a la obra (Foucault, 1990, p. 29).
\end{abstract}

Cervantes y Shakespeare inauguran la modernidad, pero no sólo en el más conocido aspecto de sus invenciones literárias: el drama y la novela modernos, rompiendo el primero con la unidad aristotélica de unidad de acción, tiempo y lugar y el segundo, con la complejidad de sus personajes, que - acompañados por la invención de Gutenberg - aprovechan ahora de un lector, que no solo oye en comunidad como en los siglos anteriores, sino que lee en soledad. Y con él, con ese lector, ambos, reinventan la distinción realidad/ficción, disolviendo y rehaciendo continuamente sus vínculos.

Es cierto que en la antigüedad el verbo deslizaba con facilidad de la realidad a la "ficción", la historia de Rómulo y Remo, nos muestra, por ejemplo, la elaboración cuidadosa de una saga: "un jefe guerrero sin familia, y por tanto remisible a una descendencia divina directa, capaz de matar al hermano - y en consecuencia de romper los vínculos de sangre - y de afirmar la inviolabilidad del nuevo espacio y de la comunidad que apenas había constituido" (Schiavone, 2012, p. 68). Ese verbo, que bien podría ser fingere, se desliza de un lado al otro de la distinción, y mantiene en el relato romano, en la memoria de Roma, al mismo tiempo la estructura y los fundamentos de la estructura, como la tríada teológica precapitolina de Júpiter, Marte y Quirino, que simbolizaba, a su vez, la unión/división de las tres tribus más antiguas: ramneses, ticios y lúceres (Schiavone, 2012, p. 71).

Pero, como afirma Raffaele De Giorgi, la memoria no es una invención reciente. Reciente es, en cambio, la reducción de la memoria a la simple facultad de conservación del pasado y a la capacidad de ordenarlo, de recordarlo, así como, sostengo, se "pretende" que ha sido. Mnemósine en el mito griego -, refiere el Profesor de Lecce, es una diosa titánide, hermana de Cronos y de Océano y madre de las musas: 
Ella - dice - tenía en la sangre (si es que los dioses tienen sangre) la circulación y la fluctuación, la unidad y la distinción, la especificación y la universalidad, la duración y la permanencia. Mnemósine tiene la tarea de presidir la función poética - que se ejercita de manera similar a la profética -. Aedo y Vate (ciegos los dos), poseídos ambos por las musas y por la divinidad, ven lo que los demás no ven; no sólo lo invisible, sino también lo que los otros no ven. Penetran en el tiempo que ya no existe y también en el tiempo que todavía no existe; ven en su inmediatez el orden del cosmos. El pasado que las hijas de Mnemósine cantan no es el pasado que ha sido (no la vulgar cronología), sino el relato de los orígenes, l'arché, la genealogía del tiempo. Pasado y futuro son presencias que giran alrededor del mundo ultraterreno. Aedo y Vate pueden en verdad entrar en el otro mundo y salir libremente de él - y con ayuda de Mnemósine narrarlo -...Mnemósine - sustraída al mito se convierte en paradoja: la paradoja de la construcción del presente en el presente. Nosotros debemos evitar la paradoja. El recuerdo de Roma o (como se sigue repitiendo) la idea de Roma, la presencia de Roma, son construcciones del observador. La Edad Media o el Renacimiento (el clasicismo o el romanticismo) han construido cada uno su propia Roma, su Roma distinta. Las realidades de Roma son las realidades de estas construcciones. El recuerdo no es la memoria. Es una parte de la distinción con la cual trabaja la memoria. La otra parte es el olvido... (De Giorgi, 2016b, p. 167).

Por ello, dice De Giorgi, parece legítimo preguntar si el derecho mismo no sea una memoria; y en efecto cuando se dice que el derecho reproduce relaciones sociales, se intenta decir que el derecho es imágenes, reproducciones de otra cosa, esto es del recuerdo de otra cosa que se imprime en el derecho y agrega: "Si el derecho reproduce estas ideas, o, asimismo, estas específicas relaciones sociales, el derecho sería, entonces, memoria. El tema sería, por tanto, un no tema, pues debería ser formulado como el derecho del derecho y esto, como se sabe, es una paradoja” (De Giorgi, 2016a, p. 149).

La memoria, dirá más adelante, es entendida como un principio explicativo (Erklärungsprinzip); ello porque los individuos inventan su memoria; la sociedad y, por consiguiente, los sistemas sociales - y, por tanto, el derecho - inventan una memoria. Se trata de probar, entonces, que la memoria y, naturalmente, también la memoria inventada por el derecho, es considerada una función que se justifica a sí misma y, consecuentemente, surge de la evolución. Los relatos inventan las comunidades, el derecho, las naciones. Dice Marisa Moyano que Eliseo Verón (1993, p. 30) señala que, refiriéndose a los "textos de fundación", 
la localización histórica de una fundación es en sí misma un producto del proceso de reconocimiento. Una fundación es inseparable del reconocimiento retroactivo del hecho de que, efectivamente, ocurrió. Es siempre después que se reconoce, en una región dada del pasado, el comienzo o recomienzo de una ciencia [...] Dicho de otra manera: "es a partir de un ideológico 'B' que opera en reconocimiento, que se pone de manifiesto un ideológico 'A' que ha operado en producción". Siguiendo este razonamiento también Arfuch sostendrá que el "contar una (la propia) historia no será entonces simplemente un intento de atrapar la referencialidad de algo sucedido, acuñado como huella en la memoria, sino que es constitutivo de la dinámica misma de la identidad: es siempre a partir de un ahora que cobra sentido un pasado, correlación siempre diferente (y diferida) sujeta a los avatares de la enunciación. Historia que no es sino reconfiguración constante de historias, divergentes, superpuestas, de las cuales ninguna puede aspirar a la mayor representatividad" (Moyano, 2005, [s. p.]).

La paradoja de la constitución de la verdad, de esas operaciones de la memoria que llamamos realidad, ocupa, en Cervantes y Shakespeare, un lugar central. Y es a partir de ellos que se produce la operación de subversión anti-mítica que aparece en el centro, por lo mismo paradojalmente mítico, de la literatura moderna.

En este punto, me parece oportuno advertirles que sostengo que la literatura de ficción, abiertamente declarada tal, refuerza consistentemente a la literatura realista, permitiendo ocultar el carácter ficcional de esta, precisamente porque al declararse ficcional permite suponer que hay "otro género", así en el Derecho como en la Historia y, a su vez, suponer que sean una "realidad".

Lo podemos ver en lo ocurrido con la memoria de Roma y su Derecho, el que, nacido del discurso mágico de los sacerdotes, fue siendo reinventado por sucesivas generaciones de juristas (y sacerdotes), y, partiendo de la Ley de las XII Tablas, llega a convertirse en el relato más grande de todos justamente con el Digesto justinianeo, en el que - como afirma Schiavone podemos ver esa operación literaria expuesta en toda su dimensión; ver, por ejemplo, los dos estratos más elementales de su escritura, la de los autores originarios de cada fragmento y la de los redactores designados por el emperador, quienes "habrían dado vida a un enredo en el cual se habrían entrecruzado continuamente lo auténtico y lo superpuesto (las así llamadas interpolaciones)" (Schiavone, 2012, p. 41), pero, a su vez, también advertir 
que algunas obras atribuidas por los justinianeos a autores de los siglos II y III d.C. (sobre todo de la época severiana) e insertadas como tales en la recopilación, no fuesen sino falsificaciones confeccionadas más tarde, y publicadas bajo el nombre de un antiguo maestro. Podríamos así decir que el Digesto completa, en varios sentidos, la obra comenzada con la Eneida. Los autores de novelas de caballería, Cervantes el último de ellos, son tributarios de este ingenio.

Borges, cuando no, sobre lo que él llama "la postulación de la realidad", con un ejemplo tomado de la obra de Gibbon (Decline and Fall of the Roman Empire, $X X X V$ ), nos advierte que ese autor nos propone un juego de símbolos, organizados rigurosamente, pero cuya animación queda a cargo nuestro, un juego que no es realmente expresivo, que no escribe sobre los primeros contactos con la realidad, sino sobre su elaboración final, lo que se trata - en suma - del mismo método utilizado por Voltaire, Swift o Cervantes,

[...] dentro de su notoria ineficacia, son eficaces: falta resolver esa contradicción. Yo aconsejaría esta hipótesis: la imprecisión es tolerable o verosímil en la literatura, porque a ella propendemos siempre en la realidad. La simplificación conceptual de estados complejos es muchas veces una operación instantánea. El hecho mismo de percibir, de atender, es de orden selectivo: toda atención, toda fijación de nuestra conciencia, comporta una deliberada omisión de lo no interesante. Vemos y oímos a través de recuerdos, de temores, de previsiones. En lo corporal, la inconsciencia es una necesidad de los actos físicos. Nuestro cuerpo sabe articular este difícil párrafo, sabe tratar con escaleras, con nudos, con pasos a nivel, con ciudades, con ríos correntosos, con perros, sabe atravesar una calle sin que nos aniquile el tránsito, sabe engendrar, sabe respirar, sabe dormir, sabe tal vez matar: nuestro cuerpo, no nuestra inteligencia. Nuestro vivir es una serie de adaptaciones, vale decir, una educación del olvido. Es admirable que la primera noticia de Utopía que nos dé Thomas More, sea su perpleja ignorancia de la "verdadera" longitud de uno de sus puentes... (Borges, 2007a, p. 254255).

\section{EL “RECURSO” A LA LOCURA}

Ahora estamos en condiciones de observar cómo el recurso a la ficción, al humor, a la locura, funcionaron como topos o lugares del relato, paradojalmente jugando con el concepto de "utopía", dado que actuaban como estratagemas útiles frente al poder de la censura que siempre pretende coser los labios de los disidentes "peligrosos". Antonin Artaud en 
el siglo XX o Julián Assange, el fundador de Weake Leaks podrían dar testimonio de esto. Noam Chomsky ha denunciado la dictadura de los medios de comunicación en los Estados Unidos, dictadura que hoy sufrimos, también en Brasil y Argentina, sólo por citar ejemplos conocidos.

Sabemos por Foucault, que la modernidad dio otro tratamiento a la locura, de la nave de los locos pasamos al hospicio. Pero también en la modernidad la locura ya no es el lugar del mal, cuando menos no necesariamente. La locura es una estrategia para ver lo que no se puede ver, para decir lo que no se puede decir.

Es justamente en "ese lugar", el de la razón perdida, donde nuestros personajes se vuelven más sabios, más cuerdos, más entrañables: "los niños, los borrachos y los locos, dicen siempre la verdad".

La locura sirve para explorar aquello que es, por primera vez, el centro de la preocupación de los filósofos y de los escritores: la condición humana. La locura es "la pregunta" sobre la condición humana, o si lo quieren, dicho de otro modo: ¿̇por qué, antes más bien, la cordura?

De la stultífera navis, de considerar a la locura como un mensaje demoníaco como el extravío o la pérdida de la razón, el humanismo comienza a pensarla como simplemente el otro lado. Erasmo comienza un camino, dirá Foucault, el descubrimiento de una locura inmanente a la razón, de una locura loca que rechaza a la locura de la razón, y de una "locura sabia" que la escucha, reconoce sus derechos de ciudadanía y se deja penetrar (Foucault, 1990, p. 62).

Como si fuesen una suerte de Jano, Cervantes y Shakespeare exploran los dos lados de la condición humana: el flanco luminoso, generoso, altruista, el flanco oscuro, ominoso, egoísta. De una parte, el Quijote, de la otra Sancho, de una parte, Lady Macbeth; de la otra el Rey Duncan; de una parte, Hamlet, de la otra Polonio:

Todas las cosas tienen dos caras - dice Sebastián Franck porque Dios ha resuelto oponerse al mundo, dejar a éste la apariencia y tomar para sí la verdad y la esencia de las cosas... Por ello, cada cosa es lo contrario de lo que parece ser en el mundo: un Sileno ${ }^{6}$ invertido... Cada cosa muestra dos caras. La cara exterior muestra la muerte; contémplese

6 Un sileno es una criatura mítica, un sátiro que primitivamente era mitad caballo y mitad hombre pero que luego se confunde con los sátiros cuasi cabríos, y que en épocas de Sócrates se representaba en pequeñas estatuas abiertas que a su interior mostraban otras figuras, como en el efecto abismo, o en las muñecas rusas o las cajas chinas. 
el interior: allí está la vida, o viceversa. La belleza encubre la fealdad, la riqueza la indigencia, la infamia la gloria, el saber la ignorancia. En suma, abrid el Sileno, encontraréis allí lo contrario de lo que el Sileno muestra. Nada que no esté hundido en la contradicción inmediata, nada que no incite al hombre a adherirse a su propia locura... En el siglo XVI, más que en ninguna época, la Epístola a los Corintios brilla con un prestigio incomparable: «Como si estuviera loco hablo» (Foucault, 1990, p. 54).

Hamlet, el extraviado príncipe de Dinamarca y Macbeth, el sangriento rey de Escocia, están unidos por el delgado hilo de la locura, simulada y real al mismo tiempo, la presencia continua de lo fantasmático y de lo demoníaco sirven de disparador para enfrentar a sus personajes con la sinrazón de la existencia. Es esto precisamente lo que lleva a Harold Bloom a postular su conocida tesis:

Los grandes villanos - Yago, Edmundo, Macbeth inventan el nihilismo occidental, y cada uno de ellos en un abismo en sí mismo. Lear y su ahijado Édgar son estudios tan profundos del tormento y resistencia humanos, que llevan resonancias bíblicas en obra prescristiana, pagana. Pero Falstaff, Rosalinda, Hamlet y Cleopatra son algo aparte en el mundo de la literatura: a través de ellos Shakespeare inventó esencialmente la personalidad humana tal como seguimos conociéndola y valorándola. Falstaff tiene prioridad en esa invención; no apreciar su tamaño personal, que sobrepasa incluso a su sublime gordura, sería pasar por alto la más grande de las originalidades shakespeareanas: la invención de lo humano (Bloom, 2001, p. 306-307).

La peste y la guerra han enfrentado a Shakespeare y Cervantes con nuestro hermano gemelo, como lo bautizaría el propio Hobbes: el miedo, $\mathrm{y}$, con ellas, la reflexión sobre el estatuto de la realidad.

En cada una de estas obras que tomamos como objeto, en el Quijote, en el Licenciado Vidriera, en Macbeth, en Hamlet, paradojal o no tan paradojalmente, el hilo que suspende la incredulidad (como dijera Coleridge) y que nos presta una óptica para “ver”, es la locura.

En Hamlet y en El Quijote, pareciera que la razón es el lado oscuro de la locura, de esa locura que mostraría el mejor flanco de nuestra condición, en Macbeth la demasía del poder en bruto se muestra en toda su patente racionalidad irracional: solo una demencial ambición de poder le permite vencer el remordimiento moral que la sangre de Duncan, el justo rey escocés asesinado, le provoca. 
Pero, como podría preguntar Raffaele De Giorgi, ¿cuál es la unidad de la distinción entre locura y razón? El observador que hace una "marca", que distingue allí donde antes solo estaba el magma del mundo, no sabe desde dónde o por qué distingue, eso sólo lo podrá hacer un observador de segundo grado, que a su vez precisa de otro observador.

La distinción locura/cordura es un relato que, a su vez, precisa de nuestra credulidad. Y la paradoja consiste en que para obtenerla es preciso borrar la distinción: fantástico/real.

El mismo Freud, al tratar la presencia de lo ominoso en las obras de arte, señala que el autor produce al comienzo en nosotros una especie de incertidumbre (ya él ha señalado que lo ominoso, se relaciona con lo novedoso, con lo desconocido) al no dejarnos colegir de entrada si se propone introducirnos en el mundo real o en un mundo fantástico creado por su albedrío, y, afirma,

como es notorio, el autor tiene derecho a hacer lo uno o lo otro, y si por ejemplo ha escogido como escenario sus figuraciones un mundo donde actúan espíritus, demonios y espectros - tal el caso de Shakespeare en Hamlet, Macbeth y, en otro sentido, en la Tempestad y Sueño de una noche de verano - hemos de seguirlo en ello y, todo el tiempo que dure nuestra entrega a su relato, tratar como una realidad objetiva ese universo por él presupuesto (Freud, 1999, p. 230).

Un recurso, señalado por Jentsch (citado por Freud), de los más infalibles para producir efectos ominosos en el cuento literario, consiste en dejar al lector en la incertidumbre sobre si un personaje es una persona humana o un autómata, pero - he aquí lo relevante del apunte para nosotros - esa incertidumbre no ocupa el centro de la escena pues, de lo contrario, el lector/espectador se vería llevado rápidamente a develar lo incierto (Freud, 1999, p. 227). Las brujas, las moiras, las apariciones, los fantasmas de Shakespeare cumplen un papel análogo.

El derecho, a su vez, también funge como un autómata, e inventa sus propios fantasmas, requiriendo, por supuesto, también de nuestra suspensión de la "suspensión de la incredulidad", el derecho requiere que creamos en la solidez de una estructura que "se desvanece en el aire", dotada como está de una "insoportable levedad" (Douglas Price, 2012). El derecho, como todos los sistemas sociales, está hecho de acumulaciones 
semánticas, de sedimentos de sentido, sobrepuestos los unos sobre los otros, como capas tectónicas, tal como el Digesto de Justiniano.

\section{El elogio de la locura}

Es este el punto entonces en donde podemos reunir nuestras ideas y anunciar una tesis presupuesta: Cervantes y Shakespeare debieron leer a Erasmo de Rotterdam, o asentarse sobre su sedimento semántico. En tanto sabemos con seguridad que Erasmo leyó la Utopía de Moro.

También sabemos que el erasmismo fue más fuerte en España que en la propia Holanda, y también que el Enquiridion o Manual del Caballero Cristiano, era conocido también como "Puñal que se tiene en la mano", pues Erasmo sabe ya de la formidable posibilidad de mudar el mundo que un libro posee.

En efecto, quien de llamarse Gerrit Gerritsz (Gerardo, hijo de Gerardo), pasó a llamarse Desiderius Erasmus, imponiéndose un nombre especular como le hubiese placido a Borges, señalaba en su famoso libro que, con la misma técnica irrisoria de la que los talentos intelectuales poco se sirven, los que realizan los actos trascendentes son los alcahuetes, los criminales, los estúpidos, los insolventes, mientras - sostiene - que el mismo Sócrates, calificado como el oráculo de Apolo, cuando trató de defender en público un asunto debió marcharse en medio de las mayores carcajadas de todo el mundo (Erasmo de Rotterdam, 1979, p. 50). Que fue esa misma sabiduría la que lo llevó a ser acusado y tener que beber la copa de cicuta. Es más, también su discípulo Platón, cuando quiso defenderlo debió retirarse y su famosa frase: "Las repúblicas serían felices si los filósofos gobernasen o filosofasen los gobernantes”, frase a la que han sido tan afectas las dictaduras variopintas de nuestro continente, y que ha resultado desmentida por la experiencia, pues no han habido experiencias más pestíferas que aquellas guiadas por los sabios.

De la estulticia, de esa forma de locura, sostiene Erasmo, han nacido los estados, la ciencia, los deleites de la vida; todos ellos se deben a la insensatez de algunos, y es de ellos de donde nacen el valor y el ingenio. La misma prudencia se debe a los locos, no a los sábios: "El sabio se refugia en los libros de los antiguos de donde no extrae sino meros artificios de palabras, mientras que el estúpido, arrimándose a las cosas que hay que experimentar, adquiere la verdadera prudencia, si no me equivoco. Parece 
que esto lo vio con claridad Homero: «El necio solo conoce los hechos»" (Erasmo de Rotterdam, 1979, p. 55), que probablemente quería decir: solo el necio conoce los hechos.

Para él, contrariamente a lo propuesto por los estoicos, son las pasiones las que nos guían a la sabiduría, es la estulticia, esa suerte de necedad consciente, de bobagem, la que hace prosperar la vida. En tanto los que como Séneca quitan del sabio toda pasión no dejan sino más bien a un nuevo dios o a una especie de demiurgo, que no se conmueve por el amor ni por la misericordia, los que así procedan - dice - deberán vivir en la República de Platón, en la región de las ideas o más bien en los Jardines de Tántalo (Erasmo de Rotterdam, 1979, p. 59).

Marcel Bataillon, probablemente el más erudito de los historiadores del erasmismo, sostiene que Cervantes es el último reflejo de Erasmo en España y Don Quijote, su fruto maduro (Bataillon, 1991). La persecución desatada por la contrarreforma no consiguió evitar que su influencia se notara tanto en la literatura religiosa como en la profana. No puede aventurarse cuáles ideas le llegan a Cervantes de las lecturas directas de Erasmo o de la influencia, pero sabemos que Erasmo y sus seguidores, por ejemplo, condenaron repetidas veces la literatura caballeresca por ser de poco provecho para el espíritu y ninguna orientación para la conducta, dato particularmente destacado por Bataillon (Fajardo, 1985).

No extrañamente, dado su espíritu liberal y humanista, Erasmo fue blanco de ataques tanto de los protestantes como de los católicos, muchas de sus ideas de renovación religiosa, eran más radicales que las del propio Lutero, pero los protestantes no le perdonaban no haberse adherido a ellos y permanecer fiel a Roma, en tanto que los monjes y frailes lo detestaban por las parodias en las que criticaba las exageradas expresiones de religiosidad "exterior" y la falta de piedad interior, de allí que se le atribuya influencia en la novela picaresca.

Cervantes es un humanista cristiano después de la Contrarreforma, pero habrá que destacar que durante el reinado de Carlos V, no se había dictado un solo auto de fe, en tanto que se transformaron en una costumbre durante el de su hijo, Felipe II. Se caracteriza para algunos por una suerte de neoplatonismo, que se manifiesta en el Quijote por la oposición entre el caballero andante y su escudero, como la contradicción entre idealismo y 
realismo, llegando a parodiar la alegoría de la caverna de Platón, con el descenso que el héroe realiza a la cueva de Montesinos.

El propio Erasmo también se ocupa de la cuestión, al sostener que en verdad que no hay diferencia entre los que se dejaban subyugar por las sombras y los que surgían de la caverna para ver las cosas a la luz, y ese contraste está planteado en el citado episodio de Montesinos, pero es entonces cuando Cervantes, según se ha afirmado, da un sorprendente vuelco: a partir de allí Don Quijote empieza a acercarse a Sancho, el representante de la realidad, en tanto que Sancho se aferrará a la ilusión de su amo.

\section{LA LOCURA: REGALO DE LA NATURALEZA}

Erasmo describe dos "tipos" de locura: una es la que emana de los infiernos y la otra, es aquella que se trata de una dulce ilusión, que libra al alma de dolorosos cuidados y la sumerge en un mar de deleites: “¿Y qué es la locura de don Quijote sino esa dulce ilusión que lo lleva a abandonar su vida rutinaria para hacer de la ficción su vida? ¿Y no es Dulcinea otra "dulce ilusión" en la cual su alma se refugia en todo momento? Luego, ¿qué importa que su verdad coincida con la realidad?” (Fajardo, 1985, p. 614). Esa locura de "baja intensidad" es la estulticia que elogia Erasmo y que “padece” El Quijote, en el Elogio podemos ver anticipado el final del caballero de la triste figura:

Tampoco lo lamentaba aquel habitante de Argos que había estado loco y se había pasado todos los días sentado solo en el teatro riendo, palmoteando, divirtiéndose, porque creía contemplar admirables tragedias, aunque de hecho no se representaba nada. Todo ello, al tiempo que se conducía correctamente en los deberes de la vida y era «agradable a los amigos, complaciente con la mujer, indulgente con los siervos y no se encolerizaba porque le destapasen una botella». Como quiera que le librase la familia de la enfermedad a fuerza de medicamentos, dijo así a los amigos, cuando hubo vuelto del todo a sus cabales: "Por Pólux, que me habéis matado, amigos. Nada me habéis favorecido arrebatándome así aquel placer y extirpando a viva fuerza aquel gratísimo error de mi mente» (Erasmo de Rotterdam, 1979, p. 74).

En el análisis de la patografía de August Strindberg, Karl Jaspers, recuerda que en el primer episodio de lo que más tarde se manifestaría como su esquizofrenia, el innovador dramaturgo sueco, tras haber compartido el lecho durante tres días con una criada, que no tardó en serle 
infiel, huyó al campo loco de celos y apareció entonces en él - según relata - la voluntad de luchar contra el Destino, para lo que de un montón de leña tomo una vara puntiaguda y larga, la convirtió en una lanza o venablo, e irrumpió en el bosque derribando a golpes las ramas de los árboles, como si las víctimas de los mismos fuesen sombríos gigantes (Jaspers, 1956, p. 37). Strindberg mismo es, sin embargo, quien nos proporciona los datos de su delirio, y los proporciona en modo tan ordenado que permite suponer que no estaba loco, desde que un loco no hubiera encontrado la etiología de su exaltación, o no podría tener memoria de los sucesos y su conexión. Pero, a su vez, señala Jaspers, asombra su persistente deseo de volverse loco, lo que se conecta con el deseo de volverse interesante "a sus propios ojos" (Jaspers, 1956, p. 39). El Quijote, por su parte, que acomete como Strindberg molinos de viento como si fuesen gigantes, podrá como Strindberg recordarlo al recuperar la cordura, cuando en acto de postrera justicia reparte sus bienes entre quienes acompañaron fielmente su locura.

Borges señala que cualquier autor hubiera cedido a la tentación de que don Quijote muriera en su ley, combatiendo con gigantes o paladines alucinatorios, reales para él. Almafuerte ${ }^{7}$ le ha reprochado a Cervantes la lucidez agónica de su héroe; pero, dice Borges, la forma de la novela exige que don Quijote vuelva a la cordura, también que ese regreso a la cordura sea más patético que morir loco. Es triste que Alonso Quijano vea que su vida entera ha sido un error y un disparate. Sin embargo, afirma, a Quijano le acompaña la misma virtud del Quijote, su coraje, antes, se enfrentó con gigantes y no tuvo miedo, ahora sabe que su vida ha sido un engaño y no siente miedo. Cervantes, aventura Borges, también próximo a morir, debió pensar que más le hubiera valido escribir libros de devoción. Su muerte se vuelve burocrática, solo testamento y confesión acciones que resultan patéticas en la boca de un hombre que antes hablaba de paladines, de hechicerías y de ínsulas, su cura insinúa la posibilidad de un milagro, o, antes bien, el retorno de esa otra zona de locura que es el sueño. Una superstición escocesa - refiere por fin el autor de El Aleph - quiere que los hombres cuerdos que están cerca de la muerte se vuelvan un poco locos y adquieran virtudes proféticas; aquí inversamente, la cercanía de la razón

Pedro Bonifacio Palacios (1854-1917), maestro y poeta, argentino conocido como Almafuerte, uno de los seudónimos que empleara en sus obras. 
devuelve la razón a un loco (Borges, 2003). Me atrevería a agregar que Macbeth cumple con la leyenda escocesa continuando con este juego de silenos entre Shakespeare y Cervantes.

Don Quijote es un elogio de la locura novelado, de la misma estulticia como Erasmo proponía, es decir, es un portador de una locura de baja intensidad, que mueve a risa, que nos aproxima al teatro del absurdo (el mismo del que Strindberg fuera un precursor), anticipándolo, negando reiteradamente el lado prosaico del mundo, a través del ridículo, de la risa. Pero esa risa pone bajo sospecha, la cordura del poder, la del barón de Glamis y de Cawdor, la risa es el puñal que se dirige al corazón de la racionalidad instrumental.

También en Hamlet la locura aparece en un sitial diferente y es el propio Polonio el que, antes las respuestas delirantes pero agudas de Hamlet, dice: "Que ingeniosas son a veces sus respuestas! Ocurrencias felices que suele tener la locura, y que ni la más sana razón y lucidez podrían soltar con tanta suerte..." (Shakespeare, 2003a, p. 124), y en el mismo instante que Hamlet simulando la locura responde a Polonio con una sentencia que da cuenta de su criterio moral: "Sí amigo; ser honrado, según anda hoy el mundo, equivale a ser escogido uno entre diez mil" (Shakespeare, 2003a, p. 123).

\section{SUSPENDAMOS LA INCREDULIDAD}

Según Coleridge, como muchas veces recordara Borges, para leer hay que suspender la incredulidad, el propio Coleridge dijo en su biografía literaria, que ese estado constituye la fe poética.

$\mathrm{Y}$, si nos atenemos al relato de Cervantes, y creo que no hay alternativa, todo se lo creyó don Quijote, y ello era razonable porque, como dice Rabelais, en el nacimiento de Gargantúa, refiriéndose al extraño modo de su parto:

Si no lo creéis nada me importa, mas un hombre de bien, un hombre de buen juicio, cree siempre cuanto se le dice o encuentra puesto por escrito. ¿No dice Salomón, Proverbiorum XIV: «Innocens credit omni verbo ${ }^{8}$, etc.?» Y San Pablo, prime Corinthio. XIII: «Charitas omnia credit ${ }^{9}$ ». Diréis: porque no hay evidencias. Mas yo os digo que sólo por esta causa deberéis creerlo con la fe más perfecta y

8 En latín: El inocente cree cuanto escucha.

9 En latín: A todo da crédito la caridad. 
consumada, pues bien dicen los de la Sorbona que la fe es la prueba de las cosas que no la tienen. ¿H Hay algo de lo que he dicho que esté en contra de nuestra ley o de nuestra fe, de la razón, o de las Santas Escrituras? Por mi parte nada encuentro escrito en todas las santas Biblias que cuanto dije se le oponga. Y, si Dios lo hubiera querido, ¿afirmaríais que no pudo hacerlo? Por favor, amigos, no embrollifollonéis nunca vuestro espíritu con tan vanos pensamientos, pues os aseguro que para Dios nada es imposible y que, si lo quisiera, las mujeres parirían en lo sucesivo hijos por la oreja (Rabelais, 2007, p. 68).

En el Quijote el recurso consiste en hacer intervenir una diversidad de voces, por de pronto Cervantes, como narrador homodiegético, esto es que interviene a la par como narrador y personaje, introduce de un modo novedoso la realidad. Darío Villanueva, Director de la Real Academia Española, en el prólogo a la segunda edición del IV Centenario, dice que estamos ante un texto

en el que da máximo aprovechamiento a las diferentes instancias que enuncian la narración para producir efectos de verosimilitud y favorecer una lectura intencionalmente realista de la novela [...] Cervantes cree en las capacidades de convicción que la palabra tiene y lo hace en un momento de transición todavía no resuelta entre la oralidad arcaica y la modernidad tipográfica. Dicho de otro modo, en El Quijote se da un uso sumamente eficaz del valor performativo - como dirían los lingüistas - de la enunciación plural para generar un discurso verosímil (Villanueva , 2015, p. xx).

Por otra parte, en la época del Quijote, aún la escritura se hacía para ser narrada, leída, contada, y el habla del Quijote como habla popular emprende otra renovación que no habría de detenerse. En tanto, Shakespeare que juega simultáneamente con la lengua de los comunes y con el habla erudita, también hace intervenir otras voces, con el recurso griego del coro, como en Enrique $V$ o Romeo y Julieta, o la interlocución del personaje con el espectador como el caso de Tyrrell en Ricardo III.

Me parece, atentos lectores y oyentes que, a estas alturas, ya empezaron a comprender que todo se trata de una ficción, un empeño de la filosofía del "Als ob"1o como decía Hans Vaihinger, como lo descubre inapelablemente el mismo Borges en Tlön, Uqbar, Orbis Tertius (Borges, 2007b).

10 En alemán: “Die Philosophie des Als-Ob”. 
Ahora, podemos comenzar a develar qué propone este ensayo: y es que la literatura nos instituye, que la literatura conserva y muda el mundo, que eso que llamamos el mundo está hecho de literatura. Y que, para cambiar el mundo, o sostenerlo, tenemos que "suspender la incredulidad".

Es decir que la literatura tiene algo que hacer, siempre. Concuerdo, parcialmente, con Richard Rorty, en que es la literatura y no la filosofía la que puede promover un sentido genuino de la solidaridad humana, en que se debe perseguir la descripción de experiencias humanas concretas, como el dolor o la traición, las que, al ser compartidas, generan la necesaria empatía desde la cual se geste la solidaridad y la compasión. Cervantes, Shakespeare y su discípulo Borges, sin dudas, son ironistas en el sentido rortyano.

Propongo pensar que Cervantes reintroduce en su novela "la realidad" con ese objeto: el de provocar la compasión por un personaje que obra como modelo de conducta. En efecto, los personajes de su obra, en la segunda mitad, han leído la primera y saben de su éxito y su influencia, el joven bachiller Sansón Carrasco le trae a Don Quijote, la noticia de que él es considerado uno de los más famosos caballeros andantes "que ha habido y habrá, en toda la redondez de la tierra”, y que esa historia ha sido contada como ya sabemos - por un sabio moro, que la compuso para universal entretenimiento de las gentes, y que ya se hayan impresos más de doce mil ejemplares de su historia (De Cervantes Saavedra, 2015, p. 567), dicho sea de paso, seis veces más que los que hicieron famoso a Lord Byron por su Childe Harold ${ }^{11}$.

Y, para dar más pábilo a la historia, es el propio Sancho quien, ante el requerimiento del Quijote, le dice que el vulgo lo tiene por grandísimo loco, y a él, a Sancho, por no menos mentecato; que los hidalgos lo acusan de haberse impuesto el "don" como prefijo, cuando es un pobre diablo con un trapo atrás y otro adelante y que los caballeros dicen que no quisieran la oposición de los hidalgos, menos de aquellos que apenas pueden disimular o no disimulan su escasa fortuna. El Quijote, excepcionalmente lúcido, responde bien a toda acusación, defendiendo "su locura", como lo hacía Hamlet frente a Polonio:

\footnotetext{
11 El poema narrativo autobiográfico que hizo famoso al poeta inglés.
} 
no es bien, sin tener conocimiento del pecado que se reprehende, llamar al pecador, sin más ni más, mentecato y tonto [...] caballero soy y caballero he de morir si place al Altísimo. Unos van por el ancho campo de la ambición soberbia; otros, por el de la adulación servil y baja; otros, por el de la hipocresía engañosa, y algunos, por el de la verdadera religión; pero yo, inclinado de mi estrella, voy por la angosta senda de la caballería andante, por cuyo ejercicio desprecio la hacienda; pero no la honra. Yo he satisfecho agravios, enderezado tuertos, castigado insolencias, vencido gigantes y atropellado vestiglos; yo soy enamorado, no más de porque es forzoso que los caballeros andantes lo sean; y siéndolo, no soy de los enamorados viciosos, sino de los platónicos continentes. Mis intenciones siempre las enderezo a buenos fines, que son de hacer bien a todos y mal a ninguno: si el que esto entiende, si el que esto trata merece ser llamado, díganlo vuestras grandezas, duque y duquesa excelentes (De Cervantes Saavedra, 2015, p. 793-794).

A su turno y sin arredrarse, marcando el continuum entre realidad y ficción, persiste en su locura coherentemente: los grandes de la tierra, Julio César, Alejandro Magno, Hércules y el Amadís de Gaula, siempre han recibido ataques a su virtud y por ello protesta por el excesivo celo histórico de Cide Hamete Benengeli que no ha ahorrado esfuerzos en contar ninguna de las tundas de palos que recibiera en sus aventuras, lo cual - según nuestro héroe - pudo haber callado por equidad: "pues las acciones que no mudan ni alteran la verdad de la historia no hay para qué escribirlas, si han de redundar en menosprecio del señor de la historia. A fe que no fue tan piadoso Eneas como Virgilio lo pinta, ni tan prudente Ulises como lo describe Homero" (De Cervantes Saavedra, 2015, p. 569). Cervantes sobriamente denuncia el efecto performativo de la literatura, sabe que la Odisea y la Eneida son obras políticas de sus tiempos, que la segunda fue encargada a Virgilio por Mecenas, consejero político de César Augusto para "probar" a los romanos el origen divino de su primer emperador y del mismo imperio.

La ficción reentra en la ficción produciendo el efecto de realidad: ahora que el Quijote está muerto, se puede dejar incierto el lugar de su muerte, para que las villas de la Mancha se disputen el honor como las siete ciudades de la Grecia lo hicieron con la de Homero (De Cervantes Saavedra, 2015, p. 1104-1105).

Hamlet quien también es devorado por la locura aun cuando simulada, reconoce que no emprende la venganza del asesinato de su padre 
y la deshonra de su madre, más por cobardía que por prudencia y al prepararse para el asalto de florete con Laertes, le solicita perdón diciendo que todo cuanto hizo al lastimar su honor fue producto de la locura, que lo hizo estando fuera de sí, que por lo tanto no es él mismo quien lo hiciera, sino su demencia. Cuando ya víctimas ambos del combate diseñado por Polonio para matar a Hamlet, Laertes confiesa su infame intriga, develando la culpa del rey y pidiendo al príncipe que se den mutuamente perdón, Hamlet obliga al rey a beber la poción de veneno e impide que lo haga Horacio quien, a su vez, proclama la línea que alienta el sentido entero de la obra:

\begin{abstract}
Mas, pues que justamente en tan siniestra ocasión habéis llegado (dirigiéndose a Forntinbrás) de la guerra de Polonia, y vosotros (dirigiéndose a los Embajadores) de Inglaterra, ordenad que estos cuerpos sean expuestos sobre un túmulo a la vista del pueblo, y dejad que yo relate al mundo, que aún lo ignora, de qué modo han ocurrido estos sucesos. Así conoceréis de actos impúdicos, sangrientos monstruosos; de muertes producidas por la astucia y la violencia, $\mathrm{y}$, como remate, de maquinaciones fallidas, cayendo por descuido sobre las cabezas de sus inventores... (Shakespeare, 2003a, p. 163).
\end{abstract}

\title{
LOS SILENOS DE ALCIBÍADES
}

Locura y cordura, seriedad y pasmo de risa o llanto, sacuden al lector o al oyente, para los que El Quijote, Hamlet o Macbeth, fueron escritos. Cervantes y Shakespeare, rechazan por diferentes vías una de las más viejas y persistentes enfermedades de Occidente y de Oriente por igual: su persistente maniqueísmo, padre de todas las dictaduras. Sus antagonistas traspasan continuamente las fronteras aceptadas, dudan, caen, vuelven sobre sus pasos, persisten en la locura de sus sueños. Miran a los dos lados, como Jano, aciertan y fallan, son justos e injustos, nobles y villanos.

El mismo Erasmo señala que

Es, ante todo, manifiesto que todas las cosas humanas, como los silenos de Alcibíades, tienen dos caras que difieren sobremanera entre sí, de modo que lo que exteriormente es la muerte, viene a ser la vida, según reza el dicho, si miras adentro; y, por el contrario, lo que parece vida es muerte; lo que hermoso, feo; lo opulento, paupérrimo; lo infame, glorioso; lo docto, indocto; lo robusto, flaco; lo gallardo, innoble; lo alegre, triste; lo próspero, adverso; lo amigable, enemigo; lo saludable, nocivo; y, en suma, veréis invertidas de súbito todas las 
cosas si abrís el sileno (Erasmo de Rotterdam, 1979, p. 56$57)^{12}$.

Shakespeare hace decir a las brujas de Macbeth, en su inquietante intervención inicial: "Cuando finalice el estruendo, cuando la batalla esté ganada y perdida”, el lector o espectador despreocupado habrá creído que es una referencia obvia a los dos lados que tiene el resultado de una batalla: vencedores y vencidos, pero, sin embargo, no es esa la interpretación más conveniente, el propio autor nos da la pista para descubrir el significado pues pocos versos más adelante dicen al unísono las "parcas": "Lo hermoso es feo, y lo feo es hermoso. iRevoleteemos por entre la niebla y el aire impuro" (Shakespeare, 2003c, p. 165). Es en estos primeros versos donde el autor anuncia el secreto de la trama: Macbeth vence y pierde al mismo tiempo, como ocurriría en un universo en el que todo acontece simultáneamente por la anulación del tiempo.

Las batallas se ganan y se pierden para ganadores y vencedores, como para Hamlet y Laertes, como para El Quijote frente al Caballero de los Espejos y el de la Blanca Luna.

La daga de la escritura es la unidad de la distinción que reúne la vida con la muerte, la ficción con la realidad, la mentira con la verdad; la pluma de quien hace la distinción no puede ver desde que lugar la distinción se formula, para hacerlo se necesita ser un observador de segundo grado.

Esa es la magia inaudita del Quijote, la hermosura de la fealdad, la de un anciano sin rasgo más destacado que el de su persistente bonhomía;

12 Como recuerda Rabelais en el prólogo de Gargantúa: "Alcibíades en el diálogo de Platón, que se titula El banquete, al elogiar a su preceptor Sócrates, príncipe, sin discusión de los filósofos, entre otras cosas dice que él se parecía a las «silenas». Las silenas eran en la antigüedad unas cajitas como las que al presente vemos en los establecimientos de los farmacéuticos, decoradas por fuera con figuras frívolas y alegres, tales como arpías, sátiros, ocas embridadas, liebres con cuernos, perros enjaezados, machos cabríos alados, cerdos coronados de rosas y otras pinturas de este género, contrahechas a placer para excitar la risa; de esta manera fue Sileno el maestro del buen Baco. Pero dentro de dichas cajas se guardaban las drogas más finas, tales como bálsamo, ámbar, almizcle, incienso, pedrerías finas y otras cosas preciosas. Así - decía- era Sócrates, porque viéndole y estimándole sólo por su exterior apariencia, no hubieseis dado por él una piel de cebolla; escuálido de cuerpo y ridículo de presencia, la nariz puntiaguda, la mirada de otro, la cara de loco, sencillo en sus costumbres, rústico en sus vestiduras, pobre de fortuna, desdichado con las mujeres, inepto para todos los oficios de la república, siempre riendo, siempre bebiendo en compañía de cualquiera, siempre burlándose y disimulando su divino saber. Pero al abrir esta caja, hubieseis encontrado dentro una celeste e inapreciable droga: entendimiento más que humano, virtudes maravillosas, valor invencible, sobriedad sin ejemplo, equilibrio, seguridad perfecta, desprecio increíble hacia todo aquello por lo que los humanos tan valerosamente vigilan, corren, trabajan, navegan y batalla)" (Rabelais, 2017, p. 7-8). 
que, salvo en un fugaz episodio, siempre sale derrotado, pero que persiste, precisamente, como si la filosofía de la segunda oportunidad, propia del pueblo judío, se le hubiera encarnado en su enjuto cuerpo, representando la búsqueda perpetuamente postergada de la justicia. Es la trágica historia de la República Española.

Esa es la negra fascinación de Macbeth, la contracara del Quijote, la fealdad de la hermosura, el lado oscuro de Kant, el "ángel del mal”, el terrible predecesor de la dinastía de los Estuardo y la sangrienta historia del imperio inglés, quien al saber la muerte de su esposa (quizás la mejor descripción jamás hecha de Lucrecia Borgia, la estricta practicante de las virtudes del Príncipe), grita fría y des-esperadamente (preanunciando a Kierkegaard):

¡Debiera haber muerto un poco después! iTiempo vendrá en que pueda yo oír palabra semejante!... El mañana y el mañana y el mañana avanzan a pequeños pasos, de día en día, hasta la última sílaba del tiempo recordable; y todos nuestros ayeres han alumbrado a los locos el camino hacia el polvo de la muerte... iExtínguete fugaz antorcha!... iLa vida no es más que una sombra que pasa, un pobre cómico que se pavonea y agita una hora sobre la escena y después no se le oye más...; un cuento narrado por un idiota, con gran aparato, y que nada significa!... (Shakespeare, 2003c, p. 207).

Macbeth duda, y en su dudar muestra la confrontación entra la ética de Erasmo y la de Maquiavelo:

Si con hacerlo quedara hecho...! Lo mejor entonces sería hacerlo sin tardanza. iSi el asesinato zanjara todas las consecuencias y con su cesación asegurase el éxito! iSi este golpe fuera el todo, sólo el todo, sobre el banco de arena y el bajío de este mundo saltaríamos la vida futura! Pero en estos casos se nos juzga aquí mismo; damos simplemente lecciones sangrientas, que, aprendidas, se vuelven para atormentar a su inventor. La justicia, con mano igual, presenta a nuestros propios labios los ingredientes del cáliz que nosotros hemos empozoñado... Él se encuentra aquí bajo una doble salvaguardia. Primeramente, soy su pariente y vasallo; dos poderosas razones contra el crimen... Además, como hospedador suyo, debiera cerrar las puertas a su asesino y no tomar yo mismo el puñal... En fin, ese Duncan ha usado tan dulcemente de su poder, tan intachable, ha sido en sus altas funciones que sus virtudes clamarían como trompetas angélicas contra el acto condenable de su eliminación (Shakespeare, 2003c, p. 175).

\section{LA UTOPÍA ENTRE LA LOCURA Y LA CORDURA}

Por boca de uno de los amigos de Hamlet sabemos que el mundo está cambiando, pero también por el mismo Príncipe que Dinamarca que 
Inglaterra entera es una cárcel, llena de celdas, calabozos y mazmorras, la realidad tiene el mismo doblez del teatro: "De donde resulta que nuestros mendigos son cuerpos, y nuestros monarcas y finchados héroes la sombra de los mendigos..."; $y$ poco más adelante tras mofarse de la perfección de la criatura humana, aceptando que vengan a alegrarle los comediantes, le responde al mismo Rosencrantz: "El que haga de rey será bienvenido; su majestad recibirá de mí el correspondiente tributo" (Shakespeare, 2003a, p. 125). La ficción bienvenida como realidad, o la realidad tratada como ficción teatral, la vida como comedia.

Cuando la ficción preparada por Hamlet da sus frutos, Polonio quien, como Macbeth, reconoce la naturaleza de su crimen, advierte que no puede pedir perdón mientras permanece en posesión de todo aquello por lo cual lo cometiera: la corona y la esposa del rey asesinado y se pregunta: "Puede uno lograr perdón reteniendo los frutos del delito? En las corrompidas corrientes de este mundo, la dorada mano del crimen puede torcer la ley, y a menudo se ha visto al mismo lucro infame sobornar la justicia" (Shakespeare, 2003a, p. 139).

En Shakespeare la utopía aparece en la desesperanza de sus antihéroes, el reproche moral que a sí mismos se hacen Macbeth o Polonio.

En Cervantes la encontramos en la quijotización de Sancho, en su buen gobierno de Barataria, en las recomendaciones del mismo Quijote para ese gobierno ${ }^{13}$, en la persistencia de seguir el sueño de su amo hasta su lecho de muerte. Por eso mismo su héroe es también un anti-héroe, uno que rescata la justicia a fuerza de recibir golpes, como el propio Cristo.

Cervantes inaugurando una época y clausurando otra, carga contra la caballería con un héroe que es "agudo" y "tonto", estulto, en suma un oxímoron, un sileno.

La locura aparece como el recurso para llamar a la justicia y la verdad: "los niños, los borrachos y los locos dicen la verdad" reza un refrán popular. Don Quijote, el Licenciado Vidriera, Macbeth, Hamlet transgreden las fronteras de lo real para traer la crítica de su sociedad "desde otro mundo", los asesinos contratados por Tyrrel para cumplir el siniestro encargo del Rey Ricardo, están a punto de desistir de asesinar a

13 Que más parecen un código deontológico para un buen juez, como me ha sugerido el profesor Rodríguez Ennes. 
los niños y se alejan, después de dar fin a su obra, "con la conciencia abrumada de remordimientos, hasta el punto de no poder hablar. Y así he dejado a los dos, para traer la noticia al sanguinario rey" (Shakespeare, 2003b, p. 1051).

\title{
FINALE MA NON TROPPO: JUSTICIA PARA LA UTOPÍA
}

En El hombre rebelde, Albert Camus, señala que hay crímenes de la pasión y crímenes de la lógica y que la frontera que los divide es incierta, frontera que, no obstante, el Código Penal distingue, bastante cómodamente, por la premeditación. Y agrega:

\begin{abstract}
Heatchcliff, en "Cumbres Borrascosas", el inolvidable romance de las hermanas Bronté, asesinaría al mundo entero por poseer a Cathie, pero no pensaría jamás que aquel asesinato pudiera ser justificado. En efecto, dice Camus, nuestros criminales modernos, contemporáneos, no son ya aquellos jóvenes desarmados que evocaban las excusas de amor (Camus, 1970, p. 9).
\end{abstract}

En otra parte he señalado que:

La búsqueda de un profundo y antiguo ligamen entre los seres humanos deviene absurda frente al absurdo que incumbe a la existencia humana. La búsqueda del vínculo que continuamente huye, es similar al esfuerzo inane que Sísifo cumple para tornar siempre al mismo punto. Los dioses, como dice Camus, han condenado a Sísifo a empujar sin fin una roca hasta la cima de una montaña, de donde la piedra torna a caer por su propio peso. Habían pensado, con algún fundamento, que no existe castigo más terrible que el trabajo inútil, sin esperanza. El vínculo humano parece, en definitiva, no ser otro que aquél de darse cuenta del absurdo y tentar superarlo. Mas el absurdo de ciertas manifestaciones retorna a reciclar el mismo vínculo, como tal podría serlo el uso de la razón tanto como la razón de la irracionalidad. Así la barbarie nazi como la barbarie stalinista, pero Stalin y Hitler no están solos. Así el holocausto del hambre a la que sujeta a miles de millones de personas el sistema económico imperante (Douglas Price, 2014, p. 60).

Creo que Macbeth podría haber sucumbido a sus escrúpulos y rechazar la siniestra seducción de su esposa, esa determinación de ceder a la obsesión del poder desnudo y sangriento, que preanuncia a la de los siniestros líderes del siglo XX, discípulos avanzados de la prescripción maquiavélica. Como a ellos, su extraña fascinación por la sangre, tal vez en la búsqueda de la eternidad perdida, lo perderá también y morirá a manos de un hombre "no nacido de vientre de mujer". Como quiera que sea, el Barón de Glamis y 
Cawdor se há transformado en la encarnación del poder despiadado, como los asesinos de los niños en Ricardo III, el mismo Macbeth reconoce que

la piedad, semejante a un niño recién nacido cabalgando desnudo en el huracán, o aun celeste querubín transportado en alas de los invisibles corceles del aire, revelaría la acción horrenda a los ojos de todos los hombres hasta apiadar las lágrimas a los vientos. No tengo otra espuela para aguijonear los flancos de mi voluntad, a no ser mi honda ambición, que salta en demasía y me arroja del otro lado... (Shakespeare, 2003, p. 175).

No es extraño que hayan sido los ingleses los que atribuyeran a Maquiavelo una frase que tampoco está en su célebre y trágico libro. En efecto: "el fin justifica los medios" es un slogan con copyright inglés, pese a que Lucrecia Borgia - de quien tal vez Shakespeare tuviera noticias para diseñar a la pérfida esposa del desdichado rey escocés - haya hecho méritos para adjudicarse los derechos de autor.

El mundo contemporáneo no parece debatirse entre el Quijote y el siniestro matrimonio escocés, antes bien la razón instrumental se enseñorea allí donde quiera que se mire. La misma historia de los Borgia aparece como una demostración de ello.

Como decía Unamuno, apenas comenzado el siglo XX y cuando aún esos crímenes de la razón no habían ocurrido en toda su extensión:

todo es una miseria, una completa miseria, a nadie le
importa nada de nada y cuando alguno trata de agitar
aisladamente este o aquél problema, se lo atribuyen a
negocio o afán de notoriedad...No se comprende aquí ya ni
la locura. Hasta el loco creen y dicen que lo será por tenerle
su cuenta y razón. Lo de la razón de la sinrazón es ya un
hecho para todos estos miserables. Si nuestro señor Don
Quijote resucitara y volviese a esta su España, andarían
buscándole una segunda intención a sus nobles desvaríos.
Si uno denuncia un abuso, persigue la injusticia, fustiga la
ramplonería, se preguntan los esclavos: ¿Qué irá buscando
con eso? ¿A qué aspira?... Fíjate y observa. Ante un acto
cualquiera de generosidad, de heroísmo, de locura, a todos
estos estúpidos bachilleres, curas y barberos de hoy no se
les ocurre preguntarse: ¿Por qué lo hará?... ¿Preguntó
acaso nunca Sancho por qué hacía Don Quijote las cosas
que hacía? (De Unamuno, 1961, p. 12).

Si la locura Quijotesca llegara a cuajar, seguía Unamuno, tendría una enorme ventaja sobre otras religiones, de una parte, su fundador, su profeta, Don Quijote, no Cervantes por supuesto, de quien no estamos seguros, dice el autor vasco, que fuese un hombre real, de carne y hueso, sino más bien sospechamos que fue una pura ficción (De Unamuno, 1961). 
Yo me atrevo ahora a añadir, ya para concluir, con cierto vicio borgeano, la suposición de que Cervantes fue pensado por Don Quijote y Shakespeare por Macbeth, pero que ambos fueron inventados por el mismo escritor que inventó El Quijote, que tampoco fue Benengeli pues a él la historia le había sido relatada.

Ambos son ya operaciones de la memoria de Occidente.

Ese perdido autor, sostengo, se propuso construir unos personajes antitéticos, intentó como los silenos de Alcibíades, mostrar las dos caras de este animal que ríe.

Por eso queda claro que, como en el mito de Sísifo, el Quijote y Macbeth siempre volverán a enfrentarse.

Pero esa es otra historia, sinceramente creo que hay en el mundo personas que hacen lo que hacen por lo que dicen que lo hacen, que, probablemente víctimas de una forma de locura de una intensidad desconocida (¿tal vez sea esa la que llamara Erasmo, estulticia?), piensan en que se puede ejercer el poder con justicia, por la justicia misma, sin valerse de ese lugar para otros ulteriores fines.

Para finalizar he reservado unas líneas de quien inventara el lugar que diera origen a la idea contenida en la frase del título de este ensayo, dice Rafael Hitlodeo:

Concedo que mis palabras les puedan parecer desagradables y molestas. Lo que no concibo es que, por lo mismo, les puedan parecer ridículas e insolentes. Si les contase lo que Platón describe en su República, y las cosas qué los utopianos hacen de su isla, les podrían parecer mejores, y ciertamente lo son, si bien extrañas. En efecto en ambos casos, todas las cosas son comunes, mientras que aquí rige la propiedad privada. Es claro, pues, que mi exposición no puede ser grata a quienes en su corazón han resuelto seguir otro camino. Les obligaría a volverse atrás. Pero ¿hay algo en ella que no pueda decirse en cualquier lugar o que sea inconveniente? Si hay que silenciar como nefastas las cosas que las corrompidas costumbres de los hombres tornan insólitas o absurdas, entonces, muchas cosas tenemos que silenciar los cristianos. Casi todo lo que Cristo nos enseñó y que, sin embargo, nos prohibió silenciar. Antes bien, nos mandó predicar en los tejados lo que se nos había dicho al oído. La mayor parte de su doctrina está más lejos de las costumbres de los cortesanos que lo pudiera estar mi discurso. Verdad es que muchos predicadores, como gente avispada que son, parecen haber seguido tu consejo. Al ver que la ley de Cristo encajaba mal en la vida de los hombres, han preferido adaptar el evangelio a la vida, moldeándolo como si fuera de plomo. ¿Y qué han logrado con tan peregrino proceder? Nada, si no 
es poder ser peores con mayor impunidad. Por todo ello, he llegado a la conclusión de que, si no se suprime la propiedad privada, es casi imposible arbitrar un método de justicia distributiva, ni administrar acertadamente las cosas humanas. Mientras aquella subsista, continuará pesando sobre las espaldas de la mayor y mejor parte de la humanidad, el angustioso e inevitable azote de la pobreza y de la miseria. Sé que hay remedios que podrían aliviar este mal, pero nunca curarlo. Puede decretarse, por ejemplo, que nadie pueda poseer más de una extensión fija de tierras. Que asimismo se prescriba una cantidad fija de dinero por ciudadano. Que la legislación vele para que el rey no sea excesivamente poderoso, ni el pueblo demasiado insolente. Que se castigue la ambición y la intriga, que se vendan las magistraturas, que se suprima el lujo y la representación en los altos cargos. Con ello se evita el que se tenga que acudir a robos y a malas artes para poder mantener el rango. Y se evita también el tener que dar dichos cargos a los ricos, que habría que dar más bien a hombres competentes. Con leyes como éstas los males presentes podrían aliviarse y atenuarse. Pero no hay esperanza alguna de que se vayan a curar, ni que las cosas vuelvan a la normalidad mientras los bienes sigan siendo de propiedad privada. Es el caso de los cuerpos débiles y enfermos que se van sosteniendo a base de medicinas. Al intentar curar una herida se pone más al vivo otra. Porque, no le demos vueltas, lo que a uno cura a otro, mata. No se puede dar nada a nadie sin quitárselo a los demás (Moro, 1984, p. 25).

Es cierto que Moro terminó el libro que dio origen a la idea de que el mundo podía ser "mudado", reconociendo que, si bien le gustaría que muchas de las cosas de la República de Utopía se implementasen en sus ciudades, no esperaba que lo fueran. El tiempo parece haberle dado la razón, pero la Utopía subsiste, parafraseando a Fernando Berri, como guía del caminante, solo "para caminar", de allí que valga recordar que existe un "Derecho al delirio", como decía Eduardo Galeano (2011)

¿Qué tal si deliramos por un ratito?

¿Qué tal si clavamos los ojos más allá de la infamia, para adivinar otro mundo posible?

El aire estará limpio de todo veneno que no provenga de los miedos humanos,

y de las humanas pasiones.

En las calles, los automóviles serán aplastados por los perros,

la gente no será manejada por los automóviles, ni será programada por el ordenador,

ni el televisor será el miembro más importante de la familia,

y será tratado como la plancha o el lavarropas

14 Transcripción del autor de este texto. 
Se incorporará a los códigos penales, el delito de estupidez que cometen quienes viven por tener o por ganar, en vez de vivir por vivir, simplemente, como canta el pájaro sin saber que canta y como juega el niño sin saber que juega.

En ningún país irán presos los muchachos que se niegan a cumplir el servicio militar, sino los que quieran cumplirlo.

Nadie vivirá para trabajar, pero todos trabajaremos para vivir.

Los economistas no llamarán nivel de vida al nivel de consumo, ni llamarán calidad de vida a la cantidad de cosas.

Los cocineros no creerán que a las langostas les encanta que las hiervan vivas;

Los historiadores no creerán que a los países les encanta ser invadidos;

Los políticos no creerán que a los pobres les encanta comer promesas;

La solemnidad se dejará de creer que es un virtud y nadie, nadie, tomará en serio a nadie que no sea capaz de tomarse el pelo.

La muerte y el dinero perderán sus mágicos poderes y ni por defunción ni por fortuna se convertirá el canalla en virtuoso caballero.

La comida no será una mercancía ni la comunicación un negocio, porque la comida y la comunicación son derechos humanos.

Nadie morirá de hambre porque nadie morirá de indigestión.

Los niños de la calle no serán tratados como si fuesen basura, porque no habrá niños de la calle.

Los niños ricos no serán tratados como si fuesen dinero, porque no habrá niños ricos.

La educación no será el privilegio de quienes puedan pagarla y la policía no será la maldición de quienes no puedan comprarla.

La justicia y la libertad, hermanas siamesas, condenadas a vivir separadas, volverán a juntarse bien pegaditas, espalda contra espalda.

En Argentina, las Locas de Plaza de Mayo, serán un ejemplo de salud mental, porque ellas se negaron a olvidar en los tiempos de la amnesia obligatoria.

La santa madre iglesia corregirá algunas erratas de las tablas de Moisés y el sexto mandamiento ordenará "festejar el cuerpo".

La iglesia también dictará otro mandamiento que se le había olvidado a dios: "Amarás a la naturaleza, de la que formas parte".

Serán reforestados los desiertos del mundo y los desiertos del alma y los desesperados serán esperados y los perdidos serán encontrados, porque ellos se desesperaron de tanto esperar y ellos se perdieron de tanto buscar.

Seremos compatriotas y contemporáneos de todos los que tengan, voluntad de belleza y voluntad de justicia, hayan nacido cuando hayan nacido y hayan vivido donde hayan vivido, sin que importe ni un poquito las fronteras del mapa ni del tiempo. 
Seremos imperfectos porque la perfección seguirá siendo, el aburrido privilegio de los dioses.

Pero en este mundo, en este mundo chambón y jodido, seremos capaces, de vivir cada día como si fuera el primero y cada noche como si fuera la última.

Erasmo, Cervantes (y su entrañable criatura), hubieran suscripto este derecho.

\section{REFERENCIAS}

ASTRANA MARÍN, L. Estudio preliminar. In: SHAKESPEARE, W. Obras Completas I. Madrid: Santillana, 2003. p. 9-105.

BATAILlON, M. Erasmo y España. México: FCE, 1991.

BLOOM, H. Shakespeare la invención de lo humano. Bogotá: Norma, 2001.

BORGES, J. L. Análisis del último capítulo del Quijote. In: BORGES, J. L. Textos recobrados 1956 - 1986. Buenos Aires: EMECÉ, 2003. p. 13-25.

BORGES, J. L. La postulación de la realidad. In: BORGES, J. L. Obras Completas I. Buenos Aires: EMECÉ, 2007a. p. 253-262.

BORGES, J. L. Tlön, Uqbar, Orbis Tertius. In: BORGES, J. L. Obras Completas I. Buenos Aires: EMECÉ, 2007b. p. 513-529.

BREUER, J. Señorita Anna O. en II. Historiales Clínicos (Breuer y Freud). In: FREUD, S.; BREUER, J. Sigmund Freud Obras Completas. Estudios sobre la histeria (J.Breuer y S.Freud). Buenos Aires: Amorrortu, 1999. p. 45-70.

BURGESS, A. Encuentro en Valladolid. El País Semanal, p. 2-12, 1967.

CAMUS, A. El hombre rebelde. Buenos Aires: Losada, 1970.

DE CERVANTES SAAVEDRA, M. El Quijote de la Mancha. Segunda Edición Conmemorativa IV Centenario Cervantes Real Academia Española y Asociación de Academias de la Lengua Española. Barcelona: Penguin Random House, 2015.

DE GIORGI, R. Memoria del Diritto. In: DE GIORGI, R. Temi di Filosofia del Diritto. Lecce: Pensa Multimedia, 2016a. p. 149-166.

DE GIORGI, R. Roma come memoria dell' evoluzione. In: RAFFAELE, D. G. Temi di Filosofia del Diritto - Volume 1. Lecce: Pensa Multimedia, 2016b. p. 167-184.

DE UNAMUNO, M. Vida de Don Quijote y Sancho según Miguel de Cervantes Saavedra. Madrid - Buenos Aires: Renacimiento, 1914.

DE UNAMUNO, M. Vida de Don Quijote y Sancho. Madrid: Espasa-Calpe, 1961.

DOUGLAS PRICE, J. E. La decisión judicial. Santa Fe: Rubinzal Culzoni, 2012. 
DOUGLAS PRICE, J. E. O lado obscuro da razāo. In: NASCIMENTO, Luciano; BENE, Catarina del. (Coord.). Filosofia do direito; estudos do Centro di Studi Sul Rischio dell'Università del Salento. Curitiba: Juruá, 2014. p. 59-70.

ECO, U. Decir casi lo mismo. Experiencias de traducción. Montevideo: Lumen, 2008.

ERASMO DE ROTTERDAM. Elogio de la locura. Madrid: Espasa-Calpe, 1979.

FAJARDO, D. Erasmo y «Don Quijote de la Mancha». Disponible en: $<$ http://cvc.cervantes.es/lengua/thesaurus/pdf/40/TH 40 003 120 0.p df $>$. Acceso em: 20 oct. 2016.

FOUCAULT, M. Historia de la Locura en la Época Clásica I. Buenos Aires: FCE, 1990.

FREUD, S. Lo ominoso. In: FREUD, S. Obras Completas - XVII. Buenos Aires: Amorrortu, 1999. p. 219-251.

GALEANO, E. El derecho al delirio. Entrevista de la TV catalana, em 23 mayo 2011. Disponible en: <https://www.youtube.com/watch?v=mpgHlB8QdQ>. Acceso em: 20 oct. 2016.

JASPERS, K. Genio y Locura. Ensayo de análisis patográfico comparativo sobre Strindberg, Van Gogh, Swedenborg y Holderlin. Madrid: Aguilar, 1956.

LUHMANN, N. Struttura della Società e Semantica. Roma-Bari: Laterza, 1983 .

MARTÍNEZ, M. V. A vueltas con la honra y el honor. Evolución en la concepción de la honra y el honor en las sociedades castellanas desde el medioevo al siglo XVII. Revista Borradores, Río Cuarto, 2008.

MORO, T. Utopía. Madrid: SARPE, 1984.

MOYANO, M. Los conceptos de "Nación" y los discursos fundacionales de la literatura nacional: La paradoja instituyente y la historia de una carencia. Espéculo: Revista de Estudios Literarios, n. 30, 2005. Disponible en: $<$ https://pendientedemigracion.ucm.es/info/especulo/numero3o/cnacion. html>. Acceso en: 20 Oct. 2016.

RABELAIS, F. Gargantúa y Pantagruel; 2. Disponible en: $<$ https://es.scribd.com/read/323699768/Gargantua-y-Pantagruel>.

Acceso en: 20 jun. 2017.

SCHIAVONE, A. IUS. La invención del derecho en Occidente. Buenos Aires: Adriana Hidalgo, 2012.

SHAKESPEARE, W. Hamlet. In: SHAKESPEARE, W. Obras Completas I. Madrid: Santillana, 2003a. p. 107-164.

SHAKESPEARE, W. La tragedia de Ricardo III. In: SHAKESPEARE, W. Obras Completas I. Madrid: Santillana, 2003b. p. 1009-1068.

SHAKESPEARE, W. Macbeth. In: SHAKESPEARE, W. Obras Completas I. Madrid: Santillana, 2003c. p. 163-210. 
VARGAS LLOSA, M. Una novela para el siglo XXI. In: CERVANTES SAAVEDRA, M. Don Quijote de la Mancha. Barcelona: Penguin Random House Grupo Editorial S.A., 2015. p. XXXV.

VILLANUEVA, D. El Quijote (1605-1615): Visión y Dicción. Cuatro siglos de modernidad de la novelística. In: DE CERVANTES SAAVEDRA, M. Don Quijote de la Mancha. Barcelona: Penguin Random House, 2015. p. XIIIXXII.

Lengua original: Español

Recibido: 15/02/17

Aceptado: 11/o3/17 